\title{
Economic efficiency of new varieties of fruit crops
}

\section{Khomenko,}

Academician NAAS, Doctor of agricultural , Professor, chief researcher

L. Kostiuk,

Ser. Laboratory research on intellectual property and marketing innovation and economics, PhD. Econ. Science, Ph.D.

\section{Mamalyha}

\section{An institute of pomology is the name of L.P. Symyrenka NAAS}

The purpose. To evaluate new and promising varieties created in the Institute of pomology. Methods. Normative, calculation. Results. Most economically efficient new and promising varieties of fruit crops, capable to ensure yield of plantations at the level of 70,9-137,5 thousands hrn/hectare are determined. Conclusions. Innovative development of Institute of pomology at their transfer into production will allow increasing productivity of plantations in gardening factories minimum for $50-70 \%$.

Key words: gardening, fruit crops, variety, evaluation, efficiency, productivity, profit.

Raising of problem. The increase of production of garden-stuffs and berries volumes in our country with the aim of reduction of part to the import and creation of additional possibilities for an export is possible on condition of increase of competitiveness of production of fruit goods and investment attractiveness of fruit business. Competitive functioning of gardening industry activation of innovative activity of enterprises, capable to provide high efficiency of menage and acquisition of competitive edges certain enterprises on internal and external markets at the improvement of organizationally-economic mechanism of innovative conduct of gardening industry, is the basis of.

Competitive activity is the propulsive factor of increase of the labour, increase of scales of production and his efficiency, upgrading of products and introduction of innovations productivity. She generates a competition environment, in the conditions of what enterprise aim to fix the economic position through bringing in of customers due to suggestion of the best commodities or advantageous terms of sale comparatively with competitors, id est coordinates the actions of market subjects without the centralized interference with their activity. [1, P. 818]. Thus only condition, that allows to the private commodity producers to get most profits, is their possibility to compete, presenting the best products at the market.

Investigating essence of concept "competitiveness", it costs to specify on the specific of his application depending on the hierarchy of object of researches. In this sense distinguish separate economic categories to the competitiveness of products, enterprise, industry and country on the whole [2, P. 306], for that general are their properties to answer the necessities of market environment, that show up in competitive edges. The last provide more strong positions at the market for every marked element. Under the market of perfect competition it follows to understand terms functioning of economy, at that the sufficient amount of customers and salespeople enters into the voluntarily acceding of purchase-sale to the aim of receipt of benefit [3].

Alluding to the theory of effective competition, O.A.Nugna [4, P. 111] marks that efficiency of activity of agrarian enterprise and his competitiveness depend on four group indexes (criteria), among that a leading place belongs to the competitiveness of commodity, efficiency of productive process, turnover means and mine-out production distribution control. Accordingly, to the tool of researches it is suggested to take profitability of production, level of the labour productivity, efficiency of the strategic planning, adaptivity, innovative activity and others like that [5, P.111]. The adopted indexes characterize efficiency of production of goods and specify on possibility of enterprise to work at the market from position of producer - only one side of participants of market relations. From the point of view of author a 
competitiveness is determined by expense-price factors, and from position of consumer - by totality of consumer-cost descriptions.

Scientists, exposing essence of category «competitiveness of products», bind her to quality or in a technical value, or in understanding of consumer properties.

P.T.Sabluk determines this category as a «commodity that has the best quality, cost and quantitative indexes next to the least cost of consumption and effective sale strategy to satisfy the necessities of consumers in relation to quality and assortment at more subzero price» [2, P. 306]. An author marks that among sizes that represent the exact meaning of competitiveness of products most, there are such, production costs, degree of satiation of products of certain market this kind, are fixed «in basis of that, level of purchasing power of population» At unsatisfactory have a drink on products the lower limit of competitiveness is determined by attitude of profit toward the charges of facilities and labour or relation of market price to the individual production costs. A «competitiveness is a derivative from a profit and public charges of labour» [ there, P. 307-308].

In scientific literature marked, that the competitiveness of agricultural produce can be determined after the simplified chart - expecting the index of norm of profit, as attitude of market price toward the individual charges of production(commercial unit cost) [6]. Taking into account it, it is suggested to use the index of level of profitability, that represents efficiency of industry(index of competitiveness) more clearly, an author.

As an additional indicator of competitiveness of products a profit margin can come forward on 1 hectare long-term planting. Such index can be determined only taking into account the specific of agriculture and possibility of enterprise on the extended recreation of all his constituents [6]. Thus, as indexes of competitiveness of gardening products there is sense to use a profit margin from 1 hectare плодоносних planting and level of profitability.

In labours of home scientists extraordinarily various methodologies of research of competitiveness of products, enterprise, industries and in general competitiveness are presented agrarian to the sector. Such methodologies, except listed above, are illuminated also in works of O. Vinogradova [7], L. Gemelinska [8], O. Fajthuk [9]. Usually, in such case for the calculation of competitiveness it is necessary to use indexes, that characterize more quality parameters, than quantitative. Most methodologies too complicate the process of estimation that does impossible their use in everyday practice. Therefore methods have the most practical value the researches of productive processes, worked out E. Krikavskij [10] but V. Mesel-Veseljak [11], on the basis of that next methodology of estimation of competitiveness of gardening products that is offered, coming from determination, that the competitiveness of products in a general view is determined by correlation of useful effect to the total expenses, that include the charges related to acquisition and exploitation of commodity, is based on the use of next indexes:

1. productivity, c/ha (t/ha);

2. productive charges, thousand $\mathrm{UAH}$ on 1 ha;

3. production, $\mathrm{UAH} / \mathrm{kg}$, c;

4. cost of realization(purchase price), $\mathrm{UAH} / \mathrm{kg}$;

5. profit on 1 hectare planting, thousands $U A H$;

6. level of profitability of production, $\%$.

7. term of recoupment of capital investments, years.

To our opinion, by an important index for the estimation of competitiveness of agricultural produce(to the gardening products in particular) the index of norm of profit that must become in a prospect, except capital and productive charges on the production of goods, with forming of market of earth, will include her market value.

For the analysis of indexes of competitiveness of products the method of comparative analysis is used. The indexes of efficiency and loud speaker of production of goods are compared.

An aim of researches is dates economic evaluation to the new and perspective varieties of selection of Institute of pomology the name of L.P.Symyrenka NAAS.

Methods of researches - normative, calculation. 
Results of researches. In Institute of pomology the name L.P.Symyrenka NAAS is investigated innovative technological decisions in gardening, that can be used in the production of garden-stuffs and berries by agricultural enterprises.

The charges of material resources, money and labour in technological experiments took into account after a normative method in obedience to Methodology of economic and power evaluation of types of planting, sorts, investments in the fixed assets, innovations and results of technological researches in gardening [12].

Objects of researches: new and perspective varieties and elite forms of fruit, baccate and not in current use cultures of selection of Institute of pomology the name L.P.Symyrenka NAAS.

The economic evaluation of new varieties and elite forms of apple-tree (table. 1) demonstrates considerably higher(in 1,5-2,5 times) efficiency of their growing comparatively with the control sort of regardless of technology of growing, to what the indexes of profitability and profitability of production testify: from 55,6 to 137,5 t. UAH/ ha (at 17,3-63,6 t. UAH/ ha at the sort of Adored) and 207,6-380,7\% (sort of Adored - 69,0-223,8\%).

Profitability of growing of new varieties of pear (seminal rootstock, chart of seating of $7 \times 4 \mathrm{M}$ ) presents a $48,8-57,6 \mathrm{t}$. UAH/ ha at a $41,3 \mathrm{t}$. UAH/ ha in a control variant. Level of profitability accordingly $300,9-$ $341,9 \%$ at $263,8 \%$ on control (table. 2.)

Growing of new varieties and elite forms of plum also is more economically more effective comparatively with a control sort Volohka: profit at their production makes a to $76,2 \mathrm{t}$. UAH/ha a $58,0 \mathrm{t}$. $\mathrm{UAH} / \mathrm{ha}$ is in a control variant), and level of profitability - to $384,1 \%(313,4$ on control) (table. 3$)$.

The economic evaluation of sorts and elite forms of cherry educed that the best indexes, among the investigated objects, a sort showed cherries Gadana (table. 4). At the chart of landing a $5 \times 4 \mathrm{~m}$ the middle productivity for $2011-2015$ on this sort made $16,2 \mathrm{t} /$ ha, that provided the level of profitability of $115 \%$. The term of recoupment of capital investments on creation of planting of this sort at such chart of landing folds 4,6. Other sorts of cherry, that was investigated, are shown by some more subzero indexes on the productivity and level of profitability. Most subzero indexes on a sort Optimist: the productivity - 13,1 $\mathrm{t} /$ ha, level of profitability - 105,1\%. Elite forms on the productivity do not yield to the sorts, providing the productivity at the level of $15 \mathrm{t} / \mathrm{ha}$ and level of profitability at the level of $110-113 \%$.

The analysis of indexes of economic efficiency of sorts and elite forms of merry (table. 5.) showed that all investigated sorts and elite forms provided the higher as compared to control level of the productivity. At the chart of landing a $6 \times 4 \mathrm{~m}$ the best productivity was shown by a sort merrys Legend Mliiv - 16,8 $\mathrm{t} / \mathrm{ha}$. Such productivity provided the level of profitability of $121,7 \%$. The term of recoupment of capital investments on creation of planting of this sort at such chart of landing folds 5,75 . The productivity of elite forms exceeds the indexes of control sort and is within the limits of the middle productivity on the investigated

sorts. 
1. Economic efficiency of new varieties and elite forms of apple-tree of selection of Institute of pomology

\begin{tabular}{|c|c|c|c|c|c|c|c|c|}
\hline Sort, elite form & $\begin{array}{l}\text { Productivity } \\
2015, \mathrm{t} / \text { ha }\end{array}$ & $\begin{array}{l}\text { Capital } \\
\text { investments, t. } \\
\text { UAH/ha }\end{array}$ & $\begin{array}{l}\text { Charges, all, t. } \\
\text { UAH/ha }\end{array}$ & $\begin{array}{l}\text { Gross receipt, t. } \\
\text { UAH/ha }\end{array}$ & $\begin{array}{l}\text { Prime price, } \\
\text { UAN/kg }\end{array}$ & $\begin{array}{l}\text { Profit, t. } \\
\text { UAH/ha }\end{array}$ & $\begin{array}{l}\text { Level of } \\
\text { profitability \% }\end{array}$ & $\begin{array}{l}\text { Term of } \\
\text { recoupment of } \\
\text { capital } \\
\text { investments, } \\
\text { years }\end{array}$ \\
\hline \multicolumn{9}{|c|}{ M. 26(without irrigation, chart of seating $4 \times 1,5 \mathrm{M}$ ) } \\
\hline Adored (c) & 5,3 & 101,0 & 25,1 & 42,4 & 4,7 & 17,3 & 69,0 & 10,8 \\
\hline Renet of Mliiv & 12,3 & 101,0 & 27,5 & 98,4 & 2,2 & 70,9 & 258,2 & 6,4 \\
\hline № 12-2-40 & 10,3 & 101,0 & 26,8 & 82,4 & 2,6 & 55,6 & 207,6 & 6,8 \\
\hline № 5-39 & 11,3 & 101,0 & 27,1 & 90,4 & 2,4 & 63,3 & 233,2 & 6,6 \\
\hline \multicolumn{9}{|c|}{ M. 26(irrigation, individual supports, chart of seating $4 \times 1,5 \mathrm{M}$ ) } \\
\hline Adored (c) & 11,5 & 119,1 & 28,4 & 92,0 & 2,5 & 63,6 & 223,8 & 6,9 \\
\hline Renet of Mliiv & 14,0 & 119,1 & 29,3 & 112,0 & 2,1 & 82,7 & 282,8 & 6,4 \\
\hline № 12-2-40 & 18,5 & 119,1 & 30,8 & 148,0 & 1,7 & 117,2 & 380,7 & 6,0 \\
\hline № 5-39 & 13,8 & 119,1 & 29,2 & 110,4 & 2,1 & 81,2 & 278,2 & 6,5 \\
\hline \multicolumn{9}{|c|}{ M. 9(irrigation, individual supports, chart of seating $3,75 \times 0,75 \mathrm{M}$ ) } \\
\hline Adored $(\mathrm{c})$ & 11,0 & 156,2 & 38,6 & 88,0 & 3,5 & 49,4 & 127,8 & 8,2 \\
\hline Renet of Mliiv & 22,5 & 156,2 & 42,5 & 180,0 & 1,9 & 137,5 & 323,2 & 6,1 \\
\hline № 12-2-40 & 17,8 & 156,2 & 40,9 & 142,4 & 2,3 & 101,5 & 247,9 & 6,5 \\
\hline № 5-39 & 18,6 & 156,2 & 41,2 & 148,8 & 2,2 & 107,6 & 261,1 & 6,5 \\
\hline
\end{tabular}


2. Economic efficiency of new varieties and elite forms of pear of selection of Institute of pomology ordinary after 2011-2015 (chart of seating of 7x4M)

\begin{tabular}{|c|c|c|c|c|c|c|c|c|c|}
\hline & Sort, elite form & $\begin{array}{l}\text { Middle } \\
\text { productivity, } \\
\text { t/ha }\end{array}$ & $\begin{array}{l}\text { Capital } \\
\text { investments, } \\
\text { t. UAH/ha }\end{array}$ & $\begin{array}{l}\text { Charges, all, t. } \\
\text { UAH/ha }\end{array}$ & $\begin{array}{l}\text { Gross } \\
\text { receipt, t. } \\
\text { UAH/ha }\end{array}$ & $\begin{array}{l}\text { Prime price, } \\
\text { UAN/kg }\end{array}$ & $\begin{array}{l}\text { Profit, t. } \\
\text { UAH/ha }\end{array}$ & $\begin{array}{l}\text { Level of } \\
\text { profitability } \\
\%\end{array}$ & $\begin{array}{l}\text { Term of } \\
\text { recoupment of } \\
\text { capital } \\
\text { investments, years }\end{array}$ \\
\hline 1 & Bere of Kyiv(c) & 11,4 & 65,8 & 15,7 & 57,0 & 1,4 & 41,3 & 263,8 & 6,6 \\
\hline 2 & Zelenka of Mliiv & 14,9 & 65,8 & 16,9 & 74,5 & 1,1 & 57,6 & 341,9 & 6,1 \\
\hline 3 & Novinka of Mliiv & 13 & 65,8 & 16,2 & 65,0 & 1,2 & 48,8 & 300,9 & 6,3 \\
\hline 4 & Elite form $38 / 16$ & 14,7 & 65,8 & 16,8 & 73,5 & 1,1 & 56,7 & 337,8 & 6,2 \\
\hline
\end{tabular}

3. Economic efficiency of new varieties and elite forms of plum of selection of Institute of pomology for 2011-2015 (chart of seating of 6x4M)

\begin{tabular}{|c|c|c|c|c|c|c|c|c|}
\hline Sort, elite form & $\begin{array}{l}\text { Middle } \\
\text { productivity, } \\
\text { t/ha }\end{array}$ & $\begin{array}{l}\text { Capital } \\
\text { investments, } \\
\text { t. UAH/ha }\end{array}$ & $\begin{array}{l}\text { Charges, all, } \\
\text { t. UAH/ha }\end{array}$ & $\begin{array}{l}\text { Gross } \\
\text { receipt, t. } \\
\text { UAH/ha }\end{array}$ & $\begin{array}{l}\text { Prime } \\
\text { price, } \\
\text { UAN/kg }\end{array}$ & $\begin{array}{l}\text { Profit, t. } \\
\text { UAH/ha }\end{array}$ & $\begin{array}{l}\text { Level of } \\
\text { profitability } \\
\%\end{array}$ & $\begin{array}{l}\text { Term of recoupment } \\
\text { of capital } \\
\text { investments, years }\end{array}$ \\
\hline Volohka (c) & 15,3 & 71,7 & 18,5 & 76,5 & 1,2 & 58,0 & 313,4 & 6,2 \\
\hline №9635 & 15,6 & 71,7 & 18,6 & 78,0 & 1,2 & 59,4 & 319,2 & 6,2 \\
\hline №9633 & 14,9 & 71,7 & 18,4 & 74,5 & 1,2 & 56,1 & 305,5 & 6,3 \\
\hline №8101 & 14,5 & 71,7 & 18,2 & 72,5 & 1,3 & 54,3 & 297,6 & 6,3 \\
\hline №7842 & 16,5 & 71,7 & 18,9 & 82,5 & 1,1 & 63,6 & 336,2 & 6,1 \\
\hline №8169 & 15,6 & 71,7 & 18,6 & 78,0 & 1,2 & 59,4 & 319,2 & 6,2 \\
\hline №7934 & 15,9 & 71,7 & 18,7 & 79,5 & 1,2 & 60,8 & 324,9 & 6,2 \\
\hline №8110 & 14,8 & 71,7 & 18,3 & 74,0 & 1,2 & 55,7 & 303,6 & 6,3 \\
\hline №8115 (Okrasa sadu) & 19,2 & 71,7 & 19,8 & 96,0 & 1,0 & 76,2 & 384,1 & 5,9 \\
\hline №8121 (Jantarna of Mliiv) & 18,3 & 71,7 & 19,5 & 91,5 & 1,1 & 72,0 & 368,6 & 6,0 \\
\hline №8124 (Prestige) & 19 & 71,7 & 19,8 & 95,0 & 1,0 & 75,2 & 380,7 & 6,0 \\
\hline №8143 (Charivnyzja) & 17,8 & 71,7 & 19,4 & 89,0 & 1,1 & 69,6 & 359,8 & 6,0 \\
\hline №12516 & 18,3 & 71,7 & 19,5 & 91,5 & 1,1 & 72,0 & 368,6 & 6,0 \\
\hline №12229 & 17,9 & 71,7 & 19,4 & 89,5 & 1,1 & 70,1 & 361,6 & 6,0 \\
\hline
\end{tabular}


4. Economic efficiency of new varieties and elite forms of cherry of Institute of pomology (2011-2015)

\begin{tabular}{|c|c|c|c|c|c|c|c|c|c|c|}
\hline Sort & Chart & $\begin{array}{l}\text { Amount } \\
\text { of trees, } \\
\text { pcs / ha }\end{array}$ & $\begin{array}{l}\text { Middle } \\
\text { productivity, } \\
\text { t/ha }\end{array}$ & $\begin{array}{l}\text { Capital } \\
\text { investments, } \\
\text { t. UAH/ha }\end{array}$ & $\begin{array}{l}\text { Charges, } \\
\text { all, t. } \\
\text { UAH/ha }\end{array}$ & $\begin{array}{l}\text { Gross } \\
\text { receipt, t. } \\
\text { UAH/ha }\end{array}$ & $\begin{array}{l}\text { Prime price, } \\
\text { UAN/kg }\end{array}$ & $\begin{array}{l}\text { Profit, t. } \\
\text { UAH/ha }\end{array}$ & $\begin{array}{l}\text { Level of } \\
\text { profitability \% }\end{array}$ & $\begin{array}{l}\text { Term of } \\
\text { recoupment of } \\
\text { capital } \\
\text { investments, } \\
\text { years }\end{array}$ \\
\hline Podbelska (c) & $5 \times 4$ & 500 & 15,2 & 54,60 & 71,65 & 152,00 & 4,71 & 80,35 & 112,1 & 4,7 \\
\hline Alpha & $5 \times 4$ & 500 & 15,8 & 54,60 & 73,87 & 158,00 & 4,68 & 84,13 & 113,9 & 4,6 \\
\hline Pamjat of Artemenko & $5 \times 4$ & 500 & 15,6 & 54,60 & 73,13 & 156,00 & 4,69 & 82,87 & 113,3 & 4,7 \\
\hline Elegantna & $5 \times 4$ & 500 & 13,2 & 54,60 & 64,24 & 132,00 & 4,87 & 67,76 & 105,5 & 4,8 \\
\hline Gadana & $5 \times 4$ & 500 & 16,2 & 54,60 & 75,35 & 162,00 & 4,65 & 86,65 & 115,0 & 4,6 \\
\hline Optimistka & $5 \times 4$ & 500 & 13,1 & 54,60 & 63,87 & 131,00 & 4,88 & 67,13 & 105,1 & 4,8 \\
\hline №4139 (Chudova) & $5 \times 4$ & 500 & 15,6 & 54,60 & 73,13 & 156,00 & 4,69 & 82,87 & 113,3 & 4,7 \\
\hline №3600 (Chance) & $5 \times 4$ & 500 & 14,6 & 54,60 & 69,43 & 146,00 & 4,76 & 76,57 & 110,3 & 4,7 \\
\hline
\end{tabular}


5. Economic efficiency of new varieties and elite forms of merry of selection of Institute of pomology (2011-2015)

\begin{tabular}{|c|c|c|c|c|c|c|c|c|c|c|}
\hline Sort & Chart & $\begin{array}{l}\text { Amount } \\
\text { of trees, } \\
\text { pcs / ha }\end{array}$ & $\begin{array}{l}\text { Middle } \\
\text { productivity, } \\
\text { t/ha }\end{array}$ & $\begin{array}{l}\text { Capital } \\
\text { investments, } t \text {. } \\
\text { UAH/ha }\end{array}$ & $\begin{array}{l}\text { Charges, } \\
\text { all, t. } \\
\text { UAH/ha }\end{array}$ & $\begin{array}{l}\text { Gross } \\
\text { receipt, t. } \\
\text { UAH/ha }\end{array}$ & $\begin{array}{l}\text { Prime } \\
\text { price, } \\
\text { UAN/kg }\end{array}$ & $\begin{array}{l}\text { Profit, t. } \\
\text { UAH/ha }\end{array}$ & $\begin{array}{l}\text { Level of } \\
\text { profitability } \%\end{array}$ & $\begin{array}{l}\text { Term of } \\
\text { recoupment of } \\
\text { capital } \\
\text { investments, } \\
\text { years }\end{array}$ \\
\hline $\begin{array}{l}\text { Drogana } \\
\text { (control) }\end{array}$ & $6 \times 4$ & 417 & 14,8 & 69,48 & 68,37 & 148,00 & 4,62 & 79,63 & 116,5 & 5,87 \\
\hline Biruza & $6 \times 4$ & 417 & 15,9 & 69,48 & 72,44 & 159,00 & 4,56 & 86,56 & 119,5 & 5,80 \\
\hline Chedrist & $6 \times 4$ & 417 & 16,3 & 69,48 & 73,92 & 163,00 & 4,53 & 89,08 & 120,5 & 5,78 \\
\hline Naiada & $6 \times 4$ & 417 & 16 & 69,48 & 72,81 & 160,00 & 4,55 & 87,19 & 119,8 & 5,80 \\
\hline Legend of Mliiv & $6 \times 4$ & 417 & 16,8 & 69,48 & 75,77 & 168,00 & 4,51 & 92,23 & 121,7 & 5,75 \\
\hline Dar of Млієва & $6 \times 4$ & 417 & 15,6 & 69,48 & 71,33 & 156,00 & 4,57 & 84,67 & 118,7 & 5,82 \\
\hline №6957 (Temp) & $6 \times 4$ & 417 & 15,7 & 69,48 & 71,70 & 157,00 & 4,57 & 85,30 & 119,0 & 5,81 \\
\hline №4383 (Elegy) & $6 \times 4$ & 417 & 15,5 & 69,48 & 70,96 & 155,00 & 4,58 & 84,04 & 118,4 & 5,83 \\
\hline
\end{tabular}




\section{Conclusion}

Thus, the estimation of competitiveness of gardening products in a general view is determined by next indexes: the productivity, productive charges, production cost, cost of realization (purchase price), profit on 1 hectare planting, level of profitability of production, term of recoupment of capital investments, years; but, in a prospect, index of norm of profit.

An economic evaluation of innovative developments of Institute of pomology is the name L.P.Symyrenka NAAS testifies that their transfer in a production will provide the increase of competitiveness of gardening products, in particular due to the increase of the productivity of the fruit planting at least on $50-70 \%$, providing profitability of production of garden-stuffs at the level of 70,9 137,5 t. UAH/ha.

\section{References}

1. Economic Encyclopedia: in 3 volumes; T.1 / redcologist: S.V.Mochny (ed.) And others. - K .: Publishing Center "Academy", 2000. - 864 p.

2. Formation and functioning of the agro-industrial market: a practical guide. / for ed. P.T.Sabluka. - K.: IAE, 2000. - $556 \mathrm{pp}$.

3. The Economics of Project Ananlisis. A Practitioner's Guide. EDI, Word Banc, 1991 - 195p.

4. Need O.A. Assessment of the level of competitiveness of agricultural enterprises / O.A.Nushnaya // Economy of agroindustrial complex. - 2001. - №5. - P. 110-115.

5. Kondratyuk O.I. Improving the competitiveness of agricultural production / Ol Kondratyuk /I Economy PAK. - 2005. - №10. - P. 109-112.

6. Brylev A. Competitiveness of Agricultural Products / A. Brylev // APK: Economics, management. 1998. - No. 10. - P. 65.

7. Vinogradov $O$. Methods of analysis of the competitiveness of innovation implementation on the basis of marketing / O. Vinogradov // Current problems of the economy - 2009. - № 1 (55) - P. 65-73.

8. Gemelinskaya L. Evaluation of the Competitiveness of Dairy Products / L. Djemelinska / Economy of the agroindustrial complex. - 2003. - No. 1. - P. 124-131.

9. Faychuk O. Estimation of production competitiveness of production according to technical parameters / O. Faychuk // Economy of agroindustrial complex. - 2004. - No. 10. - P. 134-139.

10. Krykavsky Y. Logistics for economists: подрусь. / Y. Krykavsky-Lviv: Publishing house of the National University "Lvivska Polytechnika", 2004. - 448 p.

11. Mesel-Veselyak V.Ya. Increasing the Competitiveness of the Agrarian Sector of Economy / V.Ya. Mesel-Veselyak / / Economy of agroindustrial complex. - 2007 - No. 12. - p. 8-14.

12. Methodology of economic and energy evaluation of types of plantings, varieties, investments in fixed capital, innovations and results of technological research in gardening / ed. O.M.Sheystopala. - NSC "Fruit-growing" of UAAS, IC of UAAS, 2006 - 144s. 